\title{
Risk assessment of the job tasks for heavy equipment operators
}

\author{
M. C. Carlos \& H. J. Lucero \\ School of Industrial Engineering, Mapua Institute of Technology, \\ Manila, Philippines
}

\begin{abstract}
The aim of the present study was to investigate human health risks on the job tasks of heavy equipment operators and determine a significant relationship between age, work experience and average daily working hours on the frequency of reported musculoskeletal injuries of the operators. A survey was conducted among male operators of selected heavy equipment of two construction companies. 56 operators responded to the survey regarding discomfort, interference and frequency of pain experienced as a heavy equipment operator. Results showed that neck, upper and lower back and hip problems were prevalent among the operators. Furthermore, ANOVA test results showed that years of experience had a significant effect on the operator's musculoskeletal injuries while the age of operator and daily working hours were insignificant. The interaction of age and work experience and of age and daily working hours both showed a significant effect on the frequency of reported injuries in the different parts of the body. The frequency of reported injuries was also significantly influenced by the interaction of age, years of experience and daily working hours. Current noise and illumination levels were acceptable but a hearing conservation program is recommended for hearing loss prevention.
\end{abstract}

Keywords: risks to operators, construction equipment, ergonomics, musculoskeletal injuries.

\section{Introduction}

Heavy equipment operators are exposed to risk factors considerably different from those in other construction trades. Drivers of heavy equipment are often required to drive long and sometimes irregular hours. Prolonged sitting, whole 
body vibration, and the repetitive operation of controls are major risk factors for work-related musculoskeletal disorders (WMDs) among these operators.

The Workplace Safety and Insurance Board (WSIB) in Ontario, Canada revealed that the average number of lost-time injuries (LTIs) for heavy equipment operators was 102 injuries yearly. Based on total injuries reported in $1998,29 \%$ were to the back, $12 \%$ to the shoulder or arm, and $9 \%$ to the ankle. The back injuries experienced by heavy equipment operators are higher than the industry average for construction which is $25 \%$. Researches have shown that the most common work-related symptoms reported among heavy equipment operators include shoulder problems, low back pain, stomach disorders, general fatigue, and irritability which are caused by work position, or environmental factors such as weather and noise [1-3]. Researchers have also come up with metrics on how to assess heavy equipment operators' exposure to risk [4].

In the construction industry, several studies focused on risk assessment of construction workers $[5,6]$; musculoskeletal discomfort in crane and forklift operators [7]; whole body vibration exposure of scraper operators [8]; and, workrelated musculoskeletal symptoms for construction workers [9] and prevention strategies [10]. The effects of noise exposure on heavy equipment operators have also been studied $[11,12]$.

While many studies have been done worldwide about risk analysis of construction workers including heavy equipment operators, only a few studies on risk analysis have been done in the Philippines and most of these were done in different industries [13-14]. Risk on construction projects was the main focus of previous studies [15]. A descriptive study involving heavy equipment operators' characteristics has been conducted [16]; however, risk on heavy equipment operators in construction industries in the Philippines has not been given much attention.

Construction industry in the Philippines involves dangerous work. Based on the results of the 2002/2003 survey conducted by the Bureau of Labor and Employment Statistics (BLES), the construction industry ranked 5th on the establishments with the most number of occupational accidents/injuries. This emphasizes the need to analyze the risks of the tasks of the construction workers particularly those of heavy equipment operators.

The study aims to identify the risks experienced by the heavy equipment operator by analyzing the posture, environmental factors such as noise and illumination and the other factors and to recommend proper risk mitigation strategies to reduce the risks for the workers in construction industry.

\section{Materials and methods}

\subsection{Design and procedure}

In order to determine the human health risks on the job of a heavy equipment operator, a survey was conducted using the Cornell Musculoskeletal Discomfort Questionnaires [17]. This enabled the identification of work-related injuries on the different parts of the body as well as risk measurement by multiplying the 
frequency score with the discomfort/severity score and interference score. Rapid Upper Limb Assessment (RULA) [18] was conducted on the current tasks of heavy equipment operators to analyze work posture. Two heavy equipment operators per heavy equipment type in each company were observed for both horizontal and vertical operations. Videos and pictures were used in the assessment. Interviews and actual observations during operation were done in the construction site. The working environment of the operators was assessed to determine if noise and illumination levels were within the allowable limits in compliance with the Occupational Safety and Health Standards (OSH).

After risk quantified and analysis, risk mitigation strategies and ergonomic workstation design for heavy equipment operators were developed in accordance to the Occupational Safety and Health standards for heavy equipment operators

\subsection{Participants}

Heavy equipment studied refers to the heavy-duty vehicles, specially designed for executing earthwork, lifting and roadwork operations. The study was limited to regular male operators of tower crane, mobile crane, rough terrain crane, compactor, loader, backhoe and forklift of the two construction companies, Companies E and M. Of the total of 235 operators in both companies, the sample size obtained from the sampling process was 149 operators; however, there were only 56 operators surveyed due to the availability. The survey respondents consisted of $14.29 \%$ backhoe operators, $7.14 \%$ compactor operators, $1.79 \%$ forklift operators, $14.29 \%$ loader operators, $8.93 \%$ rough terrain crane operators, $17.86 \%$ mobile crane operators and $39.29 \%$ tower crane operators.

\subsection{Measures}

RULA was used to assess the occupational risks of heavy equipment operators. A sound level meter was used to measure the noise level in the working environment. Foot-candle meter was used to measure the illumination in each heavy equipment type.

\subsection{Analysis}

Risk factors were identified per body part using the scores obtained from the questionnaire versus the frequency of related injuries. The collected data were analyzed using analysis of variance (ANOVA) to determine the effects of age, years of experience and duration of exposure of an operator on the frequency of reported injuries in the different parts of their body. These factors were derived from previous studies [19-22].

Results obtained from RULA were used to develop a right posture for heavy equipment operators through ergonomic workstation design in order to help improve the working conditions of heavy equipment operators and reduce risks. 


\section{Results}

\subsection{Postural risk analysis}

The results of the postural analysis using RULA are summarized in the table 1 . These results show that except for the rough terrain crane operator of Company $\mathrm{M}$, all of the operators are at low risk. The medium risk assessment of the rough terrain crane operator of Company $\mathrm{M}$ was due to the difference in equipment model used by the company. Company $\mathrm{M}$ used a model with a smaller driver compartment, hence, leaving very little clearance for movement of the operator. While risk levels are only low to medium, these still require further investigation and changes, if needed, so that the safety of the worker would not be at risk. Based from observations, it will be difficult to change the activities of the heavy equipment operators because their activities vary per project; therefore, it is better to correct the working posture of the.

Table 1: $\quad$ Summary of RULA results.

\begin{tabular}{|c|c|c|c|c|c|c|}
\hline \multirow{2}{*}{$\begin{array}{l}\text { List of Heavy } \\
\text { Equipment }\end{array}$} & \multicolumn{3}{|c|}{ Company E } & \multicolumn{3}{|c|}{ Company M } \\
\hline & Score & Risk Level & Action & Score & $\begin{array}{l}\text { Risk } \\
\text { Level }\end{array}$ & Action \\
\hline Mobile Crane & 3 & Low risk & $\begin{array}{l}\text { Further investigation, } \\
\text { change may be needed }\end{array}$ & 3 & Low risk & $\begin{array}{l}\text { Further investigation, } \\
\text { change may be needed }\end{array}$ \\
\hline $\begin{array}{c}\text { Rough Terrain } \\
\text { Crane }\end{array}$ & 3 & Low risk & $\begin{array}{l}\text { Further investigation, } \\
\text { change may be needed }\end{array}$ & 5 & $\begin{array}{c}\text { Medium } \\
\text { risk }\end{array}$ & $\begin{array}{l}\text { Further investigation, } \\
\text { change soon }\end{array}$ \\
\hline Tower Crane & 3 & Low risk & $\begin{array}{l}\text { Further investigation, } \\
\text { change may be needed }\end{array}$ & 3 & Low risk & $\begin{array}{l}\text { Further investigation, } \\
\text { change may be needed }\end{array}$ \\
\hline Compactor & 3 & Low risk & $\begin{array}{l}\text { Further investigation, } \\
\text { change may be needed }\end{array}$ & 3 & Low risk & $\begin{array}{l}\text { Further investigation, } \\
\text { change may be needed }\end{array}$ \\
\hline Backhoe & 3 & Low risk & $\begin{array}{l}\text { Further investigation, } \\
\text { change may be needed }\end{array}$ & 3 & Low risk & $\begin{array}{l}\text { Further investigation, } \\
\text { change may be needed }\end{array}$ \\
\hline Loader & 4 & Low risk & $\begin{array}{l}\text { Further investigation, } \\
\text { change may be needed }\end{array}$ & 3 & Low risk & $\begin{array}{l}\text { Further investigation, } \\
\text { change may be needed }\end{array}$ \\
\hline Forklift & 3 & Low risk & $\begin{array}{l}\text { Further investigation, } \\
\text { change may be needed }\end{array}$ & 3 & Low risk & $\begin{array}{l}\text { Further investigation, } \\
\text { change may be needed }\end{array}$ \\
\hline
\end{tabular}

Working in a sitting position requires the operators to constantly look up or. The survey results presented in table 2 indicate that workers suffer from work injuries in the neck, hip and back pain. 
Table 2: $\quad$ Results of musculoskeletal discomfort survey.

\begin{tabular}{|l|l|}
\hline \multicolumn{1}{|c|}{ Heavy Equipment } & \multicolumn{1}{c|}{ Body Part at Risk } \\
\hline Mobile Crane & Neck/Hip/Upper and Lower Back \\
\hline Rough Terrain Crane & Upper Back/Neck \\
\hline Tower Crane & Neck/Hip/Upper and Lower Back \\
\hline Compactor & Neck \\
\hline Backhoe & Neck \\
\hline Loader & Upper Back/Neck \\
\hline Forklift & Upper Back \\
\hline
\end{tabular}

\subsection{Noise analysis}

In Company E, the operators worked on a project site from 7:00AM to 4:00PM with one full lunchtime break of 1.5 hours; however, if the project needed to be finished immediately, operators worked for 12 hours. In Company $\mathrm{M}$, the operators worked on a project site from 7:00AM to 7:00PM with a 1.5-hour lunch break and a 15-minute break in the afternoon around 3:00PM. During their working hours, the operators were exposed to heavy equipment noise. The observed noise levels and computed permissible time exposure for the different heavy equipment are shown on table 3 .

Table 3: Heavy equipment noise emission levels.

\begin{tabular}{|c|c|c|c|c|}
\hline \multirow{2}{*}{$\begin{array}{c}\text { List of Heavy } \\
\text { Equipment }\end{array}$} & \multicolumn{2}{|c|}{ Company E } & \multicolumn{2}{c|}{ Company M } \\
\cline { 2 - 5 } & O b s e r v e d & Permissible & Observed & Permissible \\
\hline Mobile Crane & $\begin{array}{c}82 \mathrm{~dB} \text { for } 10.5 \\
\text { hours }\end{array}$ & 24.25 hours & $\begin{array}{c}84 \mathrm{~dB} \text { for } 10.25 \\
\text { hours }\end{array}$ & 18.38 hours \\
\hline $\begin{array}{c}\text { Rough Terrain } \\
\text { Crane }\end{array}$ & $\begin{array}{c}83 \mathrm{~dB} \text { for } 10.5 \\
\text { hours }\end{array}$ & 21.11 hours & $\begin{array}{c}86 \mathrm{~dB} \text { for } 10.25 \\
\text { hours }\end{array}$ & 13.93 hours \\
\hline Tower Crane & $\begin{array}{c}76 \mathrm{~dB} \text { for } 10.5 \\
\text { hours }\end{array}$ & 55.72 hours & $\begin{array}{c}78 \mathrm{~dB} \text { for } 10.25 \\
\text { hours }\end{array}$ & 42.22 hours \\
\hline Compactor & $\begin{array}{c}84 \mathrm{~dB} \text { for } 10.5 \\
\text { hours }\end{array}$ & 18.38 hours & $\begin{array}{c}82 \mathrm{~dB} \text { for } 10.25 \\
\text { hours }\end{array}$ & 24.25 hours \\
\hline Backhoe & $\begin{array}{c}88 \mathrm{~dB} \text { for } 10.5 \\
\text { hours }\end{array}$ & 10.56 hours & $\begin{array}{c}87 \mathrm{~dB} \text { for } 10.25 \\
\text { hours }\end{array}$ & 12.13 hours \\
\hline Loader & $\begin{array}{c}85 \mathrm{~dB} \text { for } 10.5 \\
\text { hours }\end{array}$ & 16 hours & $\begin{array}{c}83 \mathrm{~dB} \text { for } 10.25 \\
\text { hours }\end{array}$ & 21.11 hours \\
\hline Forklift & $\begin{array}{c}80 \mathrm{~dB} \text { for } 10.5 \\
\text { hours }\end{array}$ & 32 hours & $\begin{array}{c}80 \text { dB for } 10.25 \\
\text { hours }\end{array}$ & 32 hours \\
\hline
\end{tabular}

The formula below was used to determine the permissible exposure time of a certain noise level.

$$
\mathrm{T}=\frac{8}{2\left(\frac{\mathrm{L}-90}{5}\right)}
$$


The observed noise exposure of all equipment operators for Company E were all within the permissible level; however, the backhoe operator's exposure is very close to exceeding his permissible noise exposure. The observed noise levels of the heavy equipment of Company $M$ were all acceptable and in compliance with standards. Since in a construction project, there are two or more heavy equipment in operation at a time, the combined noise level may differ with various combinations of heavy equipment in the project site. Whereas table 3 shows the noise level of individual pieces of equipment, table 4 takes into account the likelihood that more than one piece of construction equipment would be in operation at the same time and lists the computed combined noise doses that could be expected for each type of construction operation involving the 7 types of heavy equipment under study.

Table 4: $\quad$ Noise dose for different construction operations.

\begin{tabular}{|l|c|c|}
\hline \multicolumn{1}{|c|}{ Type of Operation } & Company E & Company M \\
\hline Earthwork Operation & $254.06 \%$ & $136.47 \%$ \\
\hline Roadwork Operation & $57.13 \%$ & $42.27 \%$ \\
\hline Lifting Operation & $172.49 \%$ & $231.63 \%$ \\
\hline
\end{tabular}

The following formula was used to determine the noise dose for the different construction operations.

$$
\mathrm{D}=100\left(\Sigma \mathrm{C}_{\mathrm{i}} / \mathrm{T}_{\mathrm{i}}\right)
$$

Results showed that projects involving roadwork have acceptable noise doses while those involving earthwork and lifting may have excessive noise doses.

The most dominant source of noise for the majority of construction equipment is the engine exhaust, usually from a diesel engine. Although heavy equipment operators are exposed to construction noise, less background noise can be heard since most of the heavy equipment have enclosed operators' cabin. Inside the cabin, the observed noise level is usually acceptable.

\subsection{Illumination analysis}

Foot candle meter was placed near the controls section of the heavy equipment to measure illumination. Results are shown in table 5.

The illumination level on the different heavy equipment is acceptable and is within the standard lighting requirement of $10 \mathrm{fc}$ for general construction operations. The lighting inside the heavy equipment is not a problem since most work is done during summer time where the weather is clear. There are also light sources inside the different heavy equipment, which may be used when natural illumination is deemed insufficient by the operator. 
Table 5: $\quad$ Summary of observed illumination.

\begin{tabular}{|l|c|c|}
\hline \multicolumn{1}{|c|}{ List of Heavy Equipment } & Company E & Company M \\
\hline Mobile Crane & $11.3 \mathrm{fc}$ & $14 \mathrm{fc}$ \\
\hline Rough Terrain Crane & $14.2 \mathrm{fc}$ & $10.6 \mathrm{fc}$ \\
\hline Tower Crane & $13.1 \mathrm{fc}$ & $11 \mathrm{fc}$ \\
\hline Compactor & $18 \mathrm{fc}$ & $16 \mathrm{fc}$ \\
\hline Backhoe & $12.4 \mathrm{fc}$ & $10 \mathrm{fc}$ \\
\hline Loader & $14 \mathrm{fc}$ & $13 \mathrm{fc}$ \\
\hline Forklift & $20 \mathrm{fc}$ & $15 \mathrm{fc}$ \\
\hline
\end{tabular}

\subsection{Analysis of variance (ANOVA)}

The effects of three factors - age of the operator (A), years of experience (B) and duration of daily exposure $(\mathrm{C})$ - on reported body pain were analyzed using a three factor factorial design and a 95\% significance level. The ANOVA results are shown in table 6.

Table 6: $\quad$ ANOVA results.

\begin{tabular}{|c|c|c|c|c|c|c|c|}
\hline $\begin{array}{c}\text { Source of } \\
\text { Variation }\end{array}$ & $\mathrm{SS}$ & $\mathrm{df}$ & $\mathrm{MS}$ & $\mathrm{F}_{\text {computed }}$ & $\mathrm{F}_{\text {critical }}$ & $\mathrm{p}$ - value & Remarks \\
\hline Age (A) & 5.1444 & 2 & 2.5722 & 2.8561 & 3.051819 & 0.0604 & $\mathrm{NS}$ \\
\hline $\begin{array}{c}\text { Years of } \\
\text { Experience (B) }\end{array}$ & 21.0778 & 2 & 10.5389 & 11.7021 & 3.051819 & $<0.0001$ & $\mathrm{~S}$ \\
\hline $\begin{array}{c}\text { Duration of } \\
\text { Daily Exposure } \\
(\mathrm{C})\end{array}$ & 0.05 & 1 & 0.05 & 0.0555 & 3.899502 & 0.8141 & $\mathrm{NS}$ \\
\hline $\mathrm{AB}$ & 277.3278 & 4 & 69.33195 & 76.9842 & 2.427461 & $<0.0001$ & $\mathrm{~S}$ \\
\hline $\mathrm{AC}$ & 7.2334 & 2 & 3.6167 & 4.0159 & 3.051819 & 0.0199 & $\mathrm{~S}$ \\
\hline $\mathrm{BC}$ & 2.09998 & 2 & 1.04999 & 1.1659 & 3.051819 & 0.3142 & $\mathrm{NS}$ \\
\hline $\mathrm{ABC}$ & 114.5556 & 4 & 28.6389 & 31.7998 & 2.427461 & $<0.0001$ & $\mathrm{~S}$ \\
\hline Error & 145.9 & 162 & 0.9006 & & & & \\
\hline TOTAL & 286.7278 & 179 & & & & & \\
\hline
\end{tabular}

Of the three factors, only years of experience had a significant effect on the reported body pain. Data show that the body pains experienced by the operators do not vary significantly according to their age or the duration of exposure which was the same for all operators in both companies. Years of experience was found to be a significant factor and this could be because the years of experience measure the exposure of heavy equipment operators for a longer period of time 
and is more accurate compared to the duration of exposure which is on a daily basis. The interaction of age and duration of exposure as well as that of age and years of experience were also found to significantly affect the reported body pains. The three-factor interaction was also found to have significant effects on reported body pain.

\section{Conclusions}

\subsection{Postural analysis}

The work of a heavy equipment operator is done in a sitting position with constant up and down motion of the neck to see what the loads of the equipment; hence, they may suffer from work injuries in the neck, hip and back. These are confirmed by the survey results. In order to address this problem, the operator seat should be adjustable in height and should allow forward or backward tilting depending on the height of operation. In this way, the operators do not have to strain their necks and backs looking up or down from their position. Seats could be redesigned by incorporating springs under the seat which could be adjusted by a lever, similar to ergonomic office chairs. Based on RULA observations, the recommended maximum angle for adjustment would be $50^{\circ}$. This angle displacement would correct the angle of bending of the trunk when using a chair that does not tilt. The use of seat support could also reduce fatigue commonly encountered when sitting for extended periods. The support needs to be attached to a chair or seat via straps and should be positioned at the lower back level of the operator. The actual height of the support should range from $58-63 \mathrm{~cm}$. The ergonomic side supports are designed to cradle the kidney areas comfortably and provide lateral spinal support. A simple belt system would allow easy fastening of the support to the seat of any vehicle. With the support and adjustable seat, the operator could easily sit in correct posture and pressure and stress are taken off the neck and back muscles which decrease fatigue and increase comfort.

Even with seat support and adjustability, it is common for the neck and shoulder muscles to be strained from continuous work. Exercising every 2-3 hours can help strengthen neck and shoulder muscles. Exercising for 10 to 15 minutes before the start of work can help reduce muscle problems. The purpose of this warm up is to stretch the muscles to a more intense activity level gradually enough to prevent injury, and therefore, pain. As much as possible, operators should learn to sit and work without bending their neck.

Operators of forklift and compactor need to have a height of at least $5^{\prime}$ and not more than 5' "' in order to be comfortable with the equipment since the size of the cabin is smaller and best suited for smaller operators. Based on the data gathered, the operators with height within this range experience less body pain or no pain at all. For the loader, the cabin design was the same as that of other equipment but the driving control lever was not located in optimal position and required the operator to reach for it in an extended arm position while bending downward. The driving control lever would have to be relocated to the sitting elbow height of an average operator which is $24.3 \mathrm{~cm}$ from the floor. Operators 
of loader should have a minimum height of 5'3" to prevent musculoskeletal problems while operating the heavy equipment. Operators of tower crane/mobile crane should have a height of at least 5'4" to be fit the chair and controls of the operator's cabin. Based on the data gathered, operators with this height experience less body pain or no pain at all.

\subsection{Noise and illumination}

Although heavy equipment operators are exposed to construction noise, observed noise levels were acceptable from inside the operator's enclosed cabin; however, noise levels may vary on different project sites. To eliminate excessive noise exposure, it is advisable that the operators are involved in a Hearing Conservation Program for the prevention of noise-induced hearing loss.

Since construction is conducted in an open area, illumination levels were acceptable; however, this could be a different scenario for projects that may need a night shift. Providing proper illumination for heavy equipment operators in day and night shifts will help the operators work efficiently. The standard illumination for general construction work is at least $10 \mathrm{fc}$. For night shift work, spotlights should be provided to attain the required level of illumination.

\subsection{Conclusions from ANOVA}

Using the three-factor factorial design, it was found out that there was no significant difference between reported body pain among age groups and duration of exposure (hours/day) of operators. Age was not significant because there were operators from the young adult category with many body complaints and there were also operators from the adult category with few body complaints. Duration of exposure was also found to be insignificant to reported body pain because for both companies, the length of daily exposure of operators was almost the same for everyone regardless of the type of heavy equipment used. Years of experience was found to significantly affect reported body pain because it represented accumulated exposure. The interaction of age and years of experience also showed a significant effect on the frequency of reported injuries in the different parts of the body. Interaction of age and duration of exposure have the same result. A significant effect on the frequency of reported injuries also resulted from the interaction of age, years of experience and duration of exposure of an operator.

\subsection{Safety and risk analysis}

Musculoskeletal problems are serious injuries; however, these are often neglected by most construction workers. Based on the interview results, although pain is present and it could sometimes affect their efficiency and productivity, the operators prefer to continue with their work. The main reason for ignoring the pain they experienced was because they considered pain as a normal relative to their job. In addition, only a few of the operators mentioned that they consulted a physician when they experienced pain. The heavy equipment 
operators also rarely took time off from work as a result of musculoskeletal injuries because they were concerned with the loss of income. Most operators were on a "no work, no pay" compensation basis.

To minimize musculoskeletal discomfort and risk to safety and health, employees should have enough rest breaks scheduled to give the body time to recover from work; break time exercises and stretches strengthen the body. The operator should be aware that rest periods are important elements of the work and should be encouraged to report discomforts experienced during work. Operators should be given emergency break times when the symptoms occur and should consult a physician if needed. For its part, management should provide time off from work for any symptoms of musculoskeletal injuries suffered by heavy equipment operators. Ergonomics training can be also help to reduce the job health risks of heavy equipment operators and increase their efficiency and productivity.

\section{Recommendations}

The recommended risk mitigation strategies are summarized in table 7 .

Table 7: $\quad$ Risk mitigation strategies.

\begin{tabular}{|c|c|c|c|c|}
\hline HAZARD & RISK & $\begin{array}{l}\text { RESPONSE } \\
\text { STRATEGY }\end{array}$ & RESPONSE ACTIONS & RESPONSIBILITY \\
\hline \multirow{5}{*}{$\begin{array}{l}\text { Body Pain } \\
\text { Awkward } \\
\text { Posture } \\
\text { Repetitive } \\
\text { Motion } \\
\text { Prolonged } \\
\text { sitting }\end{array}$} & \multirow{5}{*}{$\begin{array}{l}\text { Musculo- } \\
\text { skeletal } \\
\text { Disorders }\end{array}$} & \multirow{5}{*}{ Mitigation } & Scheduling of breaks & Management \\
\hline & & & Exercise before and after work & $\begin{array}{c}\text { Operators and } \\
\text { Management }\end{array}$ \\
\hline & & & Proper way of exiting the vehicle & Operators \\
\hline & & & Shifting body positions & Operators \\
\hline & & & $\begin{array}{c}\text { Use of support and ergonomic } \\
\text { workstation design }\end{array}$ & Management \\
\hline \multirow{2}{*}{$\begin{array}{l}\text { Poor } \\
\text { Illumination }\end{array}$} & \multirow{2}{*}{$\begin{array}{l}\text { Poor } \\
\text { visibility }\end{array}$} & \multirow{2}{*}{ Mitigation } & $\begin{array}{l}\text { Provide proper illumination for } \\
\text { day and night shifts }\end{array}$ & Management \\
\hline & & & Equipment Maintenance & Operators \\
\hline $\begin{array}{l}\text { Noise } \\
\text { Exposure }\end{array}$ & $\begin{array}{c}\text { Noise- } \\
\text { induced } \\
\text { hearing } \\
\text { loss } \\
(\mathrm{NIHL})\end{array}$ & Mitigation & $\begin{array}{l}\text { Implementation of Hearing } \\
\text { Conservation Program }\end{array}$ & Management \\
\hline
\end{tabular}

This research was limited to the risk assessment for heavy equipment operators but there may be other areas in construction that are more prone to work-related accidents and injuries.

The use of more accurate devices like Biometrics electrogoniometers in measuring the posture of the operators will be a great help in producing more accurate and detailed postural results. Noise dosimeters would also be useful in measuring noise levels because they can collect full-shift noise exposure data by moving together with the workers as compared to an ordinary sound-level meter. 
Vibration was not considered in this study due to the lack of device that could measure heavy equipment vibration. This could be another risk factor for study. Measurements of the amount of vibration must be taken at all the supporting surfaces (floor, seat, back).

For future research, a bigger sample size is recommended to minimize statistical analysis errors. Daily observation and monitoring of the tasks of an operator is recommended to identify the particular task element that results to pain and/or discomfort. Since the scope of this study is heavy equipment operation during day shift only, it is also recommended that a similar study be conducted for night shift construction to provide a better understanding of the risk exposure of heavy equipment operators.

\section{References}

[1] Marks N., Health risks for heavy equipment operators, Construction Safety Magazine, 9(3), 1998.

[2] Miller, L. and Gariepy, C., Heavy mobile equipment - ergonomics and the prevention of musculoskeletal injuries, Paper presented at the BC Mines Conference, Vancouver, Canada, 2008.

[3] Ghaffari M., Alipour, A., Jensen, I., Farshad, A.A. and Vingard, E., Low back pain among Iranian industrial workers, Occupational Medicine, 56(7), pp. 455-460, 2006.

[4] Rashed T. A., Methods for assessing exposure to whole-body vibration and mechanical shocks induced during forklift operations, M.S. thesis, University of Cincinnati, 2007.

[5] Huawang Shi, Wanqing Li and Yong Deng, Applying principal component analysis and unascertained method for the analysis of construction accident risk, Journal of Computers, 5(8), pp. 1273-1280, 2010.

[6] Cho T. and Kim T., Probabilistic risk assessment for the construction phases of a bridge construction based on finite element analysis, Finite Elements in Analysis and Design, 44, pp. 383 - 400, 2008.

[7] Edwin, M. and Polychronopoulos, L., Musculoskeletal discomfort in crane and forklift operators in a New Zealand port, Paper presented at the $16^{\text {th }}$ Conference of the New Zealand Ergonomics Society, Nelson, New Zealand, 2010.

[8] Gillin E.K., Cann A., Vi, P., Eger, T., Hunt, M. and Salmoni, A., Evaluation of scraper operator exposure to whole-body vibration in the construction industry: a task analysis, Paper presented at the $1^{\text {st }}$ American Conference on Human Vibration, Morgantown, West Virginia, 2006.

[9] Wing Hong Fung, I., Wing-Yan Tam, V., Ming Tam, C. and Wang, K., Frequency and continuity of work related musculoskeletal symptoms for construction workers, Journal of Civil Engineering and Management, 14(3), pp. 183-187, 2008.

[10] Rwamamara, R., Lagerqvist, O., Olofsson, T., Johansson, M. and Kaminskas, K., Evidence-based prevention of work-related musculoskeletal 
injuries in the construction industry, Journal of Civil Engineering and Management, 16(4), pp. 499-50, 2010.

[11] Spencer, E. and Yantek, D., Heavy equipment construction noise study using dosimetry and time motion studies, Acoustical Society of America Journal, 118(3), p. 1954, 2005.

[12] Zeng, L., Chai, D., Li, H., Lei, Z. and Zhao, Y., Personal noise exposure assessment of overhead-travelling crane drivers in steel-rolling mills, Chinese Medical Journal, 120(6), pp. 684-689, 2007.

[13] Cepeda, M., Preliminary assessment of the chemical hazard potential of industrial plants in Kalookan City, Metro Manila, M.S. thesis, University of the Philippines, 1992.

[14] Concio, M. C., A descriptive study of occupational hazards, safety provisions, health services and occupational diseases in Solid Cement Corporation, B.S. Biology thesis, De La Salle University -Manila,.1993.

[15] Acacio, A., Leadership and strategic alignment in construction, Philippine Engineering Journal, 28(2), pp. 59-64, 2007.

[16] Cosiquien, M. and Yu, G., Characteristics of heavy equipment operators in the Philippines, B.S.C.E. thesis, De La Salle University-Manila, 1995.

[17] Hedge, A., Morimoto, S. and McCrobie, D., Effects of keyboard tray geometry on upper body posture and comfort, Ergonomics, 42(10), pp. 1333-1349, 1999.

[18] McAtameney, L. and Corlett, E.N., RULA: A survey method for the investigation of work-related upper limb disorders, Applied Ergonomics, 24(2), pp. 91-99, 1993.

[19] Deros, B., Daruis, D., Ismail, A. and Rahim, A., Work posture and back pain evaluation in a Malaysian food manufacturing company, American Journal of Applied Sciences, 7 (4), pp. 473-479, 2010.

[20] Pourmahabadian, M., Akhavan, M. and Azam, K., Investigation of risk factors of work-related upper-limb musculoskeletal disorders in a pharmaceutical industry, Journal of Applied Science, 8 (7), pp. 1262-1267, 2008.

[21] Salminen, S., Shift work and extended working hours as risk factors for occupational injury, The Ergonomics Open Journal, 3, pp. 14-18, 2010.

[22] Tomita, S., Arphorn, S., Muto, T., Koetkhlai, K., Naing, S. and Chaikittiporn, C., Prevalence and risk factors of low back pain among Thai and Myanmar migrant seafood processing factory workers in Samut Sakorn Province, Thailand, Industrial Health Journal, 48, pp. 283-291, 2010. 